\title{
LOS ALBORES DEL DERECHO PENAL: LA REGULACIÓN DEL PODER PUNITIVO EN LOS CÓDIGOS SUMERIOS, ACADIOS Y SEMITAS
}

\author{
Ramiro J. García Falconî* \\ Melissa Larenas Cortez**
}

\begin{abstract}
Resumen: El Derecho en general y en específico, y la regulación del poder punitivo, aparecen desde las primeras codificaciones que se conocen en la historia de la humanidad, siendo claros su carácter religioso, la lógica sacrificial y el componente de violencia que impregnan al mismo. Esta matriz punitiva se presenta tanto en los códigos sumerios y acadios, como en la legislación hebraica posterior, en las que se fusionan lo violento y lo sagrado. La ley talional ya hace su aparición, así como las estructuras sobre las cuales
\end{abstract}

* Doctor en Derecho Universidad de Sevilla, Máster en Derecho Penal Universidad de Sevilla, Máster en Ciencias Penales y Criminológicas Universidad Externado de Colombia, Catedrático de Derecho Penal de la Universidad Central del Ecuador y de la Universidad Internacional del Ecuador. San Francisco de Quito, Ecuador. Correo-e: ramiro_garcia70@hotmail.com.

** Investigadora del Instituto Ecuatoriano de Derecho Penal e Investigaciones Criminológicas. San Francisco de Quito, Ecuador. Correo-e: meli_larenas@hotmail.com. Fecha de recepción: 10 de febrero de 2016. Fecha de modificación: 3 de marzo de 2016. Fecha de aceptación: 24 de junio de 2016. Para citar el articulo: RAmiro García FALCOni, Melissa LAREnAs CorTEz. "Los albores del derecho penal, la regulación del poder punitivo en los códigos Sumerios, Acadios y Semitas", en Revista Derecho Penal y Criminología, Vol. 38, No. 102, enero-junio de 2016, Bogotá: Universidad Externado de Colombia, pp. 69-82. DOI: http://dx.doi.org/10.18601/ 01210483.v37n102.04 
se construirá posteriormente el sistema inquisitivo y algunos rasgos que sobreviven hasta nuestros días.

Palabras clave: Sagrado, Venganza; Violencia; Poder punitivo; Dios; Sacrificio; Sumerio; Acadio; Hebreo; Ur-Namma; Lipit-Ištar; Hammurabi; Ley Mosaica; Talión; Ordalía; Principio personal de la pena; Dicotomía; Herejía.

\title{
THE DAWN OF CRIMINAL LAW, REGULATION OF PUNITIVE POWER IN THE SUMERIAN, AKKADIAN AND SEMITE CODES
}

\begin{abstract}
General and special Law, the regulation of the punitive power appeared since the first codings known in the history of mankind, being clear their religious character, their sacrifice logic, and the violence element that permeate to it. This punitive matrix is found in both Sumerian and Akkadian Codes, as in the later Jewish legislation, in which violence and sacredness fuse. The Talion Law already makes its appearance, as well as the structures on which the Inquisitorial System will be later built, and some traits that survive until today.
\end{abstract}

Keywords: Sacred; Revenge; Violence; Punitive Power; God; Sacrifice; Sumerian; Akkadian; Hebrew; Ur-Namma; Lipit-Ištar; Hammurabi; Mosaic Law; Talion, Ordeal; Personal Principle of Punishment; Dichotomy; Heresy.

Si podemos señalar un par de características que definan al Derecho de la Antigüedad, sin duda son su carácter religioso, pues en todos los casos se asume la ley como procedente de la divinidad y, sin duda alguna, la naturaleza penal del mismo (LARA Peinado y LARA GonZÁlez, 2009, p. XXI). En cuanto a la primera característica, los elementos religiosos son evidentes, como testimonios, juramentos u ordalías, así como la continuidad de la venganza privada por medios como el de la Ley del Talión (CARDASCIA, 1979, pp. 169-183). La relación entre la violencia penal y lo sagrado se mantendrá presente en mayor o menor medida a lo largo de toda la historia, y su lógica sacrificial guiará el sistema de castigo hasta nuestros días, como veremos después.

\section{LA LÓGICA SACRIFICIAL COMO MATRIZ DEL PODER PUNITIVO}

Ya se señaló anteriormente que el carácter religioso constituye, sin duda, un elemento distintivo del poder punitivo desde sus orígenes. Las sociedades primitivas o más bien dicho, las de la Antigüedad, ven la pena como una forma de expiación; la rige una lógica sacrificial claramente marcada. Esto es claro en los códigos sumerios y acadios, pero es especialmente marcado en la legislación judaica: en ellos, se entrega la potestad de impartir justicia y de precautelar la ley a quienes se encuentran encargados también de administrar el rito y el sacrificio. 
Más allá del objetivo expiatorio, que siempre se alega al ejercer la violencia que implica la aplicación de una pena, más allá de la satisfacción del Dios o el aplacamiento de su ira, se trata de desviar la violencia en dirección a una víctima, de manera que la primera no se extienda y amenace a toda la sociedad, pues solo es posible engañar a la violencia, en la medida que no se le prive de cualquier salida o se le ofrezca algo que llevarse a la boca (GIRARD, 2005, p. 12). Es la comunidad entera la que el sacrificio protege de su propia violencia, es la comunidad entera la que es desviada hacia unas víctimas que le son exteriores. El sacrificio polariza sobre la víctima unos gérmenes de disensión esparcidos por doquier y los disipa proponiéndoles una satisfacción parcial (ídem, p. 15).

En las sociedades primitivas solo existe la venganza privada; esta es sustituida por una venganza pública cuando se establecen normas que definen conductas como ilícitas y se las conmina con una pena. Esta estructura sienta las bases para que, posteriormente, las sociedades "civilizadas" ejerzan esta forma de venganza a través de sus sistemas judiciales, pues como bien señala GIRARD, "no existe, en el sistema penal, ningún principio de justicia que difiera realmente del principio de venganza. El mismo principio de la reciprocidad violenta, de la retribución, interviene en ambos casos" (ídem, p. 23). Se escoge a una víctima y se ejerce la violencia sobre ella, de manera que su sacrificio impida que esta se disemine sobre todos los demás integrantes de la sociedad, su eliminación o inmolación se considera necesaria para la propia existencia social. Su papel en el ritual religioso y posteriormente, en el judicial, es fundamental, pues concentra en sí o más bien sobre sí, toda la violencia que se trata de contener. Es un chivo expiatorio, un Cordero de Dios, como lo denomina la Biblia, una persona que debe morir o sobre la que se debe ejercer la violencia, al ser sometida a un proceso, por el bien de toda la sociedad (GIRARD, 2002, p. 162). "Vosotros no sabéis nada; ni pensáis que nos conviene que un hombre muera por el pueblo, y no que toda la nación perezca" ${ }^{1}$, como señalaba gráficamente Caifás, al relevar la necesidad de matar a Jesús por el bien del pueblo judío. La relación entre la ritualidad religiosa y el poder punitivo es tan fuerte en la cultura occidental que el símbolo más importante de la cristiandad es la de un condenado cumpliendo pena.

\section{LAS PRIMERAS LEYES PENALES, LOS CÓDIGOS DE LA MESOPOTAMIA}

La primera estructura normativa de la que tenemos noticia data de 2112 a 2095 a.C. y se la conoce como el Código de Ur-Namma, rey que, de acuerdo con su propia descripción, era "aquel que, según las leyes justas del dios Babbar, estableció el reinado del Derecho en la tierra" (Thureau-Dangin, 1905, p. 266-267). De los algo más de 30 artículos que han llegado a nuestro conocimiento, al menos la mitad tienen

1 JUAN, 11: 49-50. 
un componente penal, en los que se castiga con la pena de muerte el asesinato ${ }^{2}$, el robo $^{3}$ y la violación ${ }^{4}$, mientras que para otros delitos como las lesiones ${ }^{5}$ o el perjurio $^{6}$ se establece el pago de una indemnización compensatoria ${ }^{7}$. Debe señalarse que casi cuatrocientos años antes ya se produjo la denominada Epopeya de Gilgamesh, que si bien no constituye una codificación, relata los abusos cometidos por el rey y la valoración jurídica sobre la ilegitimidad de los mismos; ya se habla de abuso del poder (RABINOVICH-Berkman, 2006, p. 125). Igualmente el Código de Urakagina de 2350 A.C., cuyo texto se desconoce, pero del que se tiene varias referencias respecto a su contenido.

Siglo y medio más tarde (1934-1924 a.C.) se dicta lo que conocemos actualmente como el Código de Lipit-Ištar, quinto rey de la dinastía de Isin. Esta codificación se compone de un prólogo y 43 artículos: en el prólogo, se insiste en el carácter divino del poder real y se define a sí mismo como el traductor de la voluntad de dios (GAUDEMET, 2006, p. 5). En este código, en el que también es marcado el acento penal, se impone la pena de muerte para los delitos de allanamiento de $\operatorname{morad}^{8} \mathrm{o}$ el de destrucción de muro9 . Llama la atención el delito de acusación falsa, para el que se impone la pena al acusador, correspondiente al delito falsamente acusado ${ }^{10}$.

A los códigos anteriores, que son sumerios, se suma otro acadio dictado en el entonces Estado de Eshnunna (1835-1795 a.C.), en el que al igual que los antes analizados, el componente penal se encuentra presente. Un rasgo fundamental que debe enfatizarse es la introducción de disposiciones talionales por primera vez, lo cual marca una clara diferencia con los de Ur-Namma y Lipit-Ištar.

$2 \S 1$. Si un hombre ha cometido un asesinato, se matará a ese hombre.

$3 \S 2$. Si un hombre ha cometido un acto de bandidaje, se le matará.

$4 \S 6$. Si un hombre, actuando indebidamente, ha desflorado a la esposa, todavía no desflorada de un hombre, se matará a ese hombre.

$5 \S 18$. Si un hombre a otro hombre, en el curso de una pelea, le ha cortado su pie, pesará diez gin de plata. § 19. Si un hombre a otro hombre le ha golpeado con un arma y le ha roto un hueso, pesará una mina de plata. $§ 20$. Si un hombre a otro hombre, le ha cortado la nariz con una arma blanca, pesará dos tercios de una mina de plata.

$6 \$ 27$. Si un hombre ha comparecido como testigo y ha sido declarado perjuro, pesará 15 GIN de plata.

7 Un GIN equivalía a 8,33 g de plata, mientras que una "mina" a 500 g de plata.

$8 \S 6$. Si un hombre ha echado abajo la puerta de la casa, que se mate al hombre que ha echado abajo la puerta de la casa.

$9 \$ 7$. Si un hombre ha horadado el muro de la casa, que se cuelgue delante de la brecha al hombre que ha horadado el muro de la casa.

$10 \S 22$. Si un hombre acusa injustamente a otro hombre de un asunto que este no conoce, este hombre que no puede aportar la prueba de su acusación soportará la pena del asunto del cual él le había injustamente acusado. 
Unos años después, es decir, entre 1790 y 1750 a.C., se produce la obra legislativa más célebre de la antigua Mesopotamia, me refiero al denominado "Código de Hammurabi", en honor al rey babilonio que lo emitió (Hammu el Grande). Algunos autores consideran que Babilonia es la bíblica Babel (CRUVEILHIER, 1938, p. 5). El rey se presenta como un pastor (rüaum) llamado por los dioses superiores para administrar justicia, aniquilando a los malos, sin abandonar a nadie, desde los fuertes hasta los débiles, introduciendo así “equilibrio y protección” (Kiitam y meecharu) (LALINDE ABADíA, 1992, p. 201). Este conjunto de normas continúa la línea marcada por los códigos de Ur-Namma y Lipit-Ištar, con un prólogo, texto de los artículos y un epílogo. Escrito en idioma acadio, presenta también al rey como portador o traductor de la voluntad divina, aunque no se diviniza a sí mismo. De hecho, la imagen del rey recibiendo la ley del Dios Sol nos recuerda el mito judaico de las tablas de la ley entregadas por Jehová a Moisés en la cima del Monte Sinaí. Pese a plantearse las normas que componen el código como expresión de la voluntad divina, puede apreciarse un marcado acento laico en las mismas; a diferencia de las normas contenidas en el Pentateuco, la mayoría de las cuales van dirigidas a la protección del dogma religioso hebreo. Las normas de Hammurabi se basan fundamentalmente en la costumbre y, evidentemente, varias existían mucho antes de su reinado, conforme lo demuestran las coincidencias con los textos de codificaciones anteriores, a las que ya nos hemos referido. Su valor radica no tanto en su originalidad, cuanto en lo escrupulosa de la técnica legislativa utilizada (CHAmBLiss, 1954, p. 20), pues las normas guardan concordancia entre sí, están agrupadas con un orden lógico y no presentan la desorganización que se aprecia en las normas bíblicas, por ejemplo, las cuales se encuentran aleatoria y caóticamente reunidas.

A diferencia de los códigos anteriores, sin embargo, en el de Hammurabi se limita en mucho la compensación económica a la víctima, destinándose esta posibilidad solamente a quienes se encuentran en un estamento superior, cuando el delito ha sido cometido en persona de un esclavo o subordinado (quien reviente el ojo, rompa un hueso o saque un diente), pues cuando las personas intervinientes son del mismo nivel, se contempla una práctica que más tarde se denominará con el término latino de "talión", que básicamente consiste en devolver al ofensor el mismo mal que ha causado (LALINDE ABADÍA, op. cit., p. 220). Este mecanismo ya había sido introducido anteriormente en el Código de Eshnunna, pero es en el de Hammurabi en el que se lo regula de mejor forma. Como hemos señalado, la legislación babilónica, de la cual el Código de Hammurabi es su ejemplo más elaborado, no parte del ideal de la igualdad ante la ley, pues tanto la concepción de delito como la pena a ser aplicada variarán de acuerdo al estatus social del ofensor y de la víctima (KOSCHAKER, 1991, p. 64). Romper un diente a un aristócrata por parte de otro del mismo nivel podría merecer la aplicación de la ley taliónica, pero si el ofendido era un esclavo o individuo de menor nivel, con el pago de una pequeña suma habría sido suficiente.

Llama la atención, sin embargo, que en el caso de delitos cometidos en actividades mercantiles, la penalización dirigida a los individuos de alto estrato era mucho mayor 
que a los de niveles subalternos, pues al parecer se esperaba de ellos mayor honorabilidad en estos ámbitos. Incluso se instituye el uso de documentos que certifiquen los montos involucrados en actos de comercio ${ }^{11}$. Estas descripciones típicas respecto de actos fraudulentos de comercio o adulteración de pesos y medidas, que datan de hace casi cuatro milenios, nos muestran que la preocupación por la indemnidad del sistema comercial y monetario no es producto privativo de nuestro "nuevo" Derecho penal económico ${ }^{12}$.

Si bien más de un autor ha tratado el tema del talión como una forma de expresión del principio de proporcionalidad en la aplicación de pena, vale señalar que su aparición supone una clara agravación de las consecuencias del delito, que, como hemos visto anteriormente y salvo unas cuantas excepciones en que se aplicaba la pena de muerte, siempre navegaba en aguas de la compensación económica. Debe añadirse, además, que en algunos casos se rompía el principio de personalidad de la pena, pues si un constructor negligente ocasionaba la muerte del hijo de otra persona por derrumbamiento de la construcción, en aplicación de la ley talional, quien debía morir no era el constructor, sino su hijo. De la misma forma, si un hombre casado violaba a una mujer virgen, el padre de la víctima podía violar a la mujer del violador y mantenerla retenida. Las penas son, además, de especial dureza; así, en caso de aborto voluntario, la mujer es empalada, privada de sepultura y maldita, en el caso de adulterio in fraganti, la mujer debía ser ahogada. La pena de muerte es utilizada manera recurrente en esta legislación, pero también en este caso de manera diferenciada, dependiendo del estatus social del ofensor y de la víctima. Conductas que en igualdad de condiciones podía merecer la pena de muerte o castigo corporal, quedaban satisfechas con el pago de una suma de dinero si la víctima era de estatus social inferior que su ofensor (KOSCHAKER, 1917, p. 49. § 196) ${ }^{13}$.

De las 282 disposiciones contenidas en el Código de Hammurabi que han llegado a nuestro conocimiento, podría señalarse que el menos 101 son de contenido netamente penal, lo cual nos muestra una evolución social clara en relación con las codificaciones anteriores y muchas de las posteriores, en las que el Derecho se concebía fundamentalmente desde la aplicación del poder punitivo. Evidentemente, la sociedad

$11 \S 104$. Si un mercader ha confiado a un traficante lana, aceite o cualquier mercancía para comerciar, el traficante anotará la plata y la entregará al mercader; el traficante obtendrá una tablilla sellada mencionado en ella la plata que habrá de entregar al mercader.

$12 \S 108$. "Si una tabernera no quiere recibir grano como precio por una bebida y recibe plata por el peso grande, o si disminuye la cantidad de la bebida, caso de que acepte como pago el valor del grano, lo probarán contra la tabernera y la arrojarán al agua". En primer lugar debe tomarse en cuenta que las tabernas en la Antigua Mesopotamia no solo funcionaban como sitio de expendio de bebidas, sino de los más variados productos, es decir, era una especie de supermercado de la época, en el que entre lo ofertado se encontraban personas destinadas a la prostitución.

13 Si un señor ha reventado el ojo de otro señor, se le reventará su ojo. § 197. Si un señor ha roto el hueso de otro señor, se le romperá su hueso. § 198. Si ha reventado el ojo o roto el hueso de un subalterno, pesará una mina de plata. 
babilónica de la época tenía un alto nivel de desarrollo económico y político, lo cual se demuestra en las regulaciones contenidas en el código analizado. La muerte, que se impone como pena para casi cuarenta delitos, podía aplicarse entre otros modos por ahogamiento, fuego o empalamiento, mientras que los castigos corporales consistían en golpes y azotes, así como en la mutilación de miembros u órganos.

Un aspecto que debe destacarse es que en el Código de Hammurabi, a la hora de determinar la punibilidad de una conducta, no solo se atendía al daño producido, sino a la intencionalidad del autor e incluso se toman en cuenta causas de justificación ${ }^{14}$. Se reconoce, por ejemplo, la inimputabilidad de los animales, a diferencia de las legislaciones anteriores y muchas de las posteriores, que consideraban a los animales como penalmente imputables ${ }^{15}$. Toma en cuenta aspectos como nuestro actual caso fortuito o fuerza mayor, expresados bajo la fórmula de "golpe de un Dios", como eximente de responsabilidad ${ }^{16}$, e incluso la responsabilidad del propietario negligente de un animal bravo por los daños que este hubiera podido ocasionar, con lo cual se hace una diferenciación clara, además, entre la conducta dolosa y la culposa ${ }^{17}$.

La exquisitez legislativa mostrada en el Código de Hammurabi va a niveles como el reconocer el error como eximente de responsabilidad penal ${ }^{18}$, así como la estructura del delito culposo ${ }^{19}$. Ya se encuentra presente el delito de homicidio por mala práctica profesional ${ }^{20}$, y se tipifica también la mala práctica médica ${ }^{21}$. Vemos que esta "novelería", como ha sido calificada por algunos gremios profesionales, tiene casi cuatro mil años de antigüedad.

$14 \S 135$. Si un señor es hecho cautivo y no hay en su casa lo suficiente para vivir, su esposa puede entrar en la casa de otro hombre; si así lo hace la mujer no tiene culpa.

$15 \S 250$. Si un buey, al pasar por la calle, ha acorneado a un señor y le ha causado la muerte, este caso no entraña reclamación.

$16 \$ 249$. Si un señor ha alquilado un buey y un dios le ha golpeado y muere, el señor que había alquilado el buey pronunciará el juramento por el dios y quedará en libertad.

$17 \S 251$. Si un buey de un señor es bravo y el consejo de su distrito le informa de que es bravo, pero él no ha cubierto sus astas ni ha vigilado de cerca su buey y el buey acorneó a un hijo de un señor y le ha matado, dará media mina de plata.

$18 \$ 227$. Si un señor ha engañado a un barbero y éste ha borrado la marca de un esclavo que no es suyo, se dará muerte a ese señor y se le colgará en su propia puerta. En cuanto al barbero, jurará: "le he borrado la marca sin saberlo" y quedará en libertad.

19 § 267. Si un pastor ha sido negligente y ha permitido propagarse la sarna en la majada, el pastor asumirá la culpa de la sarna que ha dejado propagar en la majada y restituirá el ganado mayor y menor y lo restituirá a su propietario.

$20 \S 229$. Si un albañil ha edificado una casa para un señor, pero no ha dado solidez a la obra y la casa que construyó se ha desplomado y ha causado la muerte del propietario de la casa, ese albañil recibirá la muerte.

$21 \S 218$. Si un médico ha llevado a cabo una operación de importancia en un señor con una lanceta de bronce y ha causado la muerte de ese señor o si ha abierto la cuenca del ojo de un señor con la lanceta de bronce y ha destruido el ojo de ese señor, se le amputará su mano. 
Sin duda, el delito analizado y tipificado de manera recurrente, en todas sus formas, en el Código de Hammurabi, es el de homicidio, al que se le imponen penas por demás severas, al igual que al de violación de domicilio o allanamiento de morada, como hemos analizado ya anteriormente (Manzini, 1903, p. 26). Pese a todos estos avances, no se encuentra exento este código de instituciones como el sacrificio ${ }^{22}$ o la ordalía ${ }^{23}$, lo cual, sin embargo, no obsta para que se reconozca al mismo como una obra jurídica de enorme elaboración y complejidad, teniendo en cuenta el contexto histórico en el que fue emitido.

El descubrimiento de tablas de origen hitita hizo pensar a algunos historiadores que se encontraban frente a un nuevo código, lo cual, por descubrimientos y análisis posteriores, ha sido de alguna forma desechado (LARA PEINADO y LARA GONZÁLEZ, op. cit., p. XLVIII).Sin embargo, de estos vestigios podemos afirmar que el Derecho penal hitita se encontraba regido por dos líneas fundamentales; por una parte, la consagración jurídica de la venganza privada, tanto respecto del delincuente, como de sus herederos, como de la venganza pública, que tenía un carácter religioso y expiatorio. Su concepción de delito no se basa en la materialidad del daño, sino en la intencionalidad con la que se cometió la conducta. La venganza privada se autoriza en un solo caso: el del marido respecto de la mujer adúltera y su amante. La venganza pública, en cambio, era ejercida por el poder estatal y se fundamentaba en la expiación por una parte y la intimidación por otra (CUQ, 1929, pp. 488 y ss.).

\section{EL PODER PUNITIVO EN EL ANTIGUO ISRAEL}

A diferencia de la rigurosa técnica que muestra el Código de Hammurabi, vemos que las normas contenidas en el Pentateuco bíblico o Torá se encuentran caóticamente diseminadas y sin criterio alguno de agrupación. La primera norma a la que hace referencia es oral e impartida por el propio dios a Adán y Eva, me refiero a la prohibición de comer del fruto del árbol del conocimiento. Posteriormente, se hace referencia a delitos cometidos e imposición de penas, como el caso de la muerte de Abel en manos de su hermano Caín e incluso el exterminio de casi toda la humanidad, excepto la familia de Noé, pero la primera codificación real se produce con el aparecimiento de la ley mosaica, esto es, la entrega de las tablas de la ley por parte de Jehová a Moisés en la cima del Monte Sinaí. Cabe señalar que en el caso bíblico no solo se asume la ley como la expresión de la voluntad divina, sino sobre todo como la materialización de la alianza entre dios y el pueblo elegido. La promesa que hiciera en su momento a los patriarcas Abraham, Isaac y Jacob se concreta con la

$22 \S 110$. Si una sacerdotisa que no vive en el claustro ha abierto una taberna o entra allí para tomar cerveza, esa mujer será quemada.

$23 \S 132$. Si la esposa de un señor es señalada con el dedo por culpa de otro varón, pero no ha sido sorprendida cohabitando con el otro hombre, por su marido, ella se arrojará al río. 
entrega de la ley al pueblo. Posteriormente, en el templo de Jerusalén, se reservará la nave central del mismo y el lugar preferente para guardar el arca que contenía las tablas de la ley "escritas por Jehová con su dedo". El nexo entre la divinidad y el pueblo se encuentra, por tanto, materializado en forma de La Ley.

Esta ley o, más bien, este conjunto de normas dispares regulaban los diferentes aspectos de la vida del pueblo judío, pero se encontraba fuertemente marcada por su carácter religioso por una parte, y por su impronta penal por otra. Bien se cuidó Moisés de advertir e incluso amenazar con maldiciones eternas a quien desobedeciere la ley ${ }^{24}$, pero también entendió que las penas debían ser cumplidas en este mundo y no solo en escenarios extraterrenos. Vemos que se hace uso de la pena capital de manera recurrente para delitos como homicidio intencional ${ }^{25}$, falso testimonio en casos de suma gravedad ${ }^{26}$, idolatría ${ }^{27}$, secuestro de un israelita ${ }^{28}$, incesto, homosexualidad y bestialidad ${ }^{29}$, violación ${ }^{30}$, adulterio ${ }^{31}$, ciertas prácticas sexuales extramaritales ${ }^{32}$, falsas profecías ${ }^{33}$, magia, adivinación y brujería ${ }^{34}$, violación del Sabbath o día de descanso ${ }^{35}$, blasfemia ${ }^{36}$, golpear o maldecir a los padres ${ }^{37}$ y ciertos delitos contra el

24 Deuteronomio, 23,1 “si desoyeres la voz de Jehová y sus Diez Mandamientos,... vendrán sobre ti todas estas maldiciones y te alcanzarán... Maldito serás tú en la ciudad y en el campo... Maldito el fruto de tu vientre, y el fruto de tu tierra, y la cría de tus vacas, y los rebaños de tus ovejas... Y Jehová enviará contra ti la maldición, quebranto y asombro en todo cuanto pusieres mano e hicieres, hasta que seas destruido y perezcas presto a causa de la maldad de tus obras, por las cuales me habrás dejado... Y serás por pasmo, por ejemplo y por fábula, a todos los pueblos de la tierra... ".

25 Éxodo, 21:12; Levítico 24:17; Números 35: 16-21, Números 35: 16-21, 35: 29-34.

26 Deuteronomio 19: 16-21.

27 Éxodo, 20: 3-5; Levítico 20: 1-5; Números, 25: 1-9; Deuteronomio, 13: 19.02; Deuteronomio, 17 : 2-7; 1 Reyes, 15: 11- 13; 2 Reyes 10: 18-28.

28 Éxodo, 21:16; Deuteronomio, 24: 7.

29 Éxodo, 22:19; Levítico, 20: 11-17.

30 Deuteronomio, 22: 23 al 27; llama la atención en esta norma que si la mujer violada no gritaba pidiendo ayuda, también debía ser ejecutada.

31 Levítico, 20: 10-12; Deuteronomio, 22:22.

32 Levítico, 21: 9; Deuteronomio, 22: 20-21, Deuteronomio, 22: 20-21, 22: 23-24.

33 Deuteronomio, 13: 1-5; Deuteronomio, 18: 20-22; 1 Reyes, 22: 19-28; Jeremías, 26: 9, Jeremías, 26 : 9, 26: 15-16; Jeremías, 28: 5-9.

34 Éxodo, 22:18; Levítico, 19:26, Levítico, 19:26, treinta y un después de las siete de la tarde; Levítico, 20: 6, Levítico, 20: 6, 20:27; Deuteronomio, 18:10; 1 Samuel, 28: 3, 1 Samuel, 28: 9.

35 Éxodo, 20: 8-11; Éxodo, 23:12 Éxodo, 31: 14-17; Éxodo, 34:21; Éxodo, 35: 1; Éxodo, 35: 1; 2: 1; Levítico, 23: 3; Números, 15: 32-36; Nehemías, 13: 15-22.

36 Levítico, 24: 14-16, Levítico, 24: 14-16, 24:23; 1 Reyes, 21:13.

37 Éxodo, 21:15, Éxodo, 21:15, 21:17. 
rey ${ }^{38}$. La pena capital no tenía una forma única de ejecutarse; de hecho, se hacía a través de lapidación ${ }^{39}$, quema ${ }^{40}$, con golpe de espada ${ }^{41}$, decapitación ${ }^{42}$ y a flechazos ${ }^{43}$.

Una característica básica de la ley hebrea es la severidad con la que se castigan tanto los delitos contra la divinidad, como contra la moral y buenas costumbres (GOLDSTEIN, 1947, p. 70). El componente de venganza privada se mantiene latente, no solo a través de la ley taliónica, sino que se constituye en el eje alrededor del cual se construye el sistema de castigo ${ }^{44}$. La pena en el caso de la ley hebraica, al igual que con la codificación de Hammurabi, no comprende solamente al culpable, sino también a la familia, animales y $\operatorname{cosas}^{45}$, y puede llegar en términos de venganza hasta la cuarta generación ${ }^{46}$. La pena se encuentra impregnada de tal forma por un componente de venganza, que incluso se establecen las jerarquías de los vengadores y se remarca la importancia del vengador de la sangre ${ }^{47}$.

En cuanto al Derecho penal sustantivo, se contempla la posibilidad del error como eximente o al menos atenuante de la responsabilidad, tanto en lo individual ${ }^{48}$ como

38 Samuel, 20:31; 1 Samuel, 22: 7 a 19; 2 Samuel, 12: 5; 2 Samuel, 13:30; 2 Samuel, 15:12; 2 Samuel, 16: 5-9, 2 Samuel, veintiún después de las cuatro de la tarde; 1 Reyes, uno y veintiún, 1 Reyes, una y cincuenta y uno; 1 Reyes, 2: 22-25; 1 Reyes, 12: 18-19; 1 Reyes, 21:10.

39 Éxodo, 19:13; Levítico, 20:27; Levítico, 24:14; Deuteronomio, 22:24; Josué, 07:25; 1 Reyes, 21:13

40 Génesis, 38:24; Levítico, 20:14; Levítico, 21: 9.

41 Deuteronomio, de las 13:15; 1 Reyes, 18:40; 2 Reyes, 23:20.

42 Reyes, 6: 31-32; comparar 2 Samuel, 16: 9.

43 Éxodo, 19:13.

44 Éxodo, 9: 5 y 6 "la sangre no puede ser lavada más que por la sangre”; Números, 25: 27 y 28 "ningún rescate por la vida de un asesino"; Segunda de Samuel, 5: 6 "la venganza se ejerce: 1. Contra el asesino; 2. Contra el violador; 3 . Contra el adúltero; 4. Contra el ladrón”.

45 Josué, 7: 19 a 25; "Entonces Josué dijo a Acán: Hijo mío, da gloria a Jehová el Dios de Israel, y dale alabanza, y declárame ahora lo que has hecho; no me lo encubras. Y Acán respondió a Josué diciendo: Verdaderamente yo he pecado contra Jehová el Dios de Israel, y así y así he hecho... Entonces Josué, y todo Israel con él, tomaron a Acán hijo de Zera, el dinero, el manto, el lingote de oro, sus hijos, sus hijas, sus bueyes, sus asnos, sus ovejas, su tienda y todo cuanto tenía, y lo llevaron todo al valle de Acor. Y le dijo Josué: ¿Por qué nos has turbado? Túrbete Jehová en este día. Y todos los israelitas los apedrearon, y los quemaron después de apedrearlos".

46 Números, 14: 18; "Jehová, que es tardo para la ira y grande en misericordia, que perdona la iniquidad y la transgresión y que no deja impune al culpable; que visita la maldad de los padres sobre los hijos hasta la tercera y cuarta generación".

47 Deuteronomio, 35: 19 "El vengador de la sangre, él dará muerte al homicida; cuando lo encontrare, él lo matará".

48 Levítico, 4:2 habla a los hijos de Israel y diles: Cuando alguna persona pecare por yerro en alguno de los mandamientos de Jehová sobre cosas que no se han de hacer, e hiciere alguna de ellas; 5:15 Cuando alguna persona cometiere falta, y pecare por yerro en las cosas santas de Jehová, traerá por su culpa a Jehová un carnero sin defecto de los rebaños, conforme a tu estimación en siclos de plata del siclo del santuario, en ofrenda por el pecado. 5:16 Y pagará lo que hubiere defraudado de las cosas santas, y añadirá a ello la quinta parte, y lo dará al sacerdote; y el sacerdote hará expiación por él con 
en lo colectivo ${ }^{49}$, sea cual fuere la falta y permitiendo que aun las más graves puedan ser perdonadas con un sacrificio expiatorio.

En lo procesal, la oralidad rige al proceso penal en el antiguo Israel y el testimonio se constituye en la prueba fundamental para adoptar una decisión (Pérez Prendes, 1970 , p. 112), sin que, como ya se analizó, se acepte un solo testimonio para fundamentar la sentencia de condena a muerte. En el proceso existe una amplia intervención de la comunidad, y en un período posterior se instituyen jueces especializados (PAVLY, 1896).

En materia probatoria, se contempla la ordalía en el caso de la mujer adúltera (CoHEN, 1965, pp. 103-115), que no hubiere sido descubierta pero de quien sospechare su marido y haga conocer su sospecha al sacerdote ${ }^{50}$. Sin embargo, llama la atención una disposición del Deuteronomio, en la que se exige más de un testimonio para que se condene a muerte a una persona ${ }^{51}$, la cual constituye, sin duda, un antecedente de la exigencia de multiplicidad de pruebas, para construir la certeza que justifique una condena y del principio de inocencia como tal. Las penas normalmente eran impuestas por un sacerdote, pero eran ejecutadas por todo el pueblo.

\section{ESTRUCTURA DICOTÓMICA DEL PODER PUNITIVO EN EL MUNDO HEBREO}

Debe tomarse en cuenta que la cohesión del pueblo judío no descansaba en su ubicación geográfica, pues tanto la etapa de esclavitud en Egipto, el cautiverio en Babilonia y, posteriormente, la diáspora implicaron alejamiento de los territorios que consideraban les habían sido asignados por la divinidad, sino en su pertenencia racial (todos descienden de las doce tribus de Israel) y de su religión común. El pueblo judío del Antiguo Testamento es fundamentalmente teocrático y se considera a Jehová como el supremo legislador y del que emanan, directamente o a través de sus sacerdotes o levitas, las disposiciones que regulaban su convivencia.

el carnero del sacrificio por el pecado, y será perdonado. 5:17 Finalmente, si una persona pecare, o hiciere alguna de todas aquellas cosas que por mandamiento de Jehová no se han de hacer, aun sin hacerlo a sabiendas, es culpable, y llevará su pecado. 5:18 Traerá, pues, al sacerdote para expiación, según tú lo estimes, un carnero sin defecto de los rebaños; y el sacerdote le hará expiación por el yerro que cometió por ignorancia, y será perdonado. 5:19 Es infracción, y ciertamente delinquió contra Jehová.

49 Levítico, 4:13 Si toda la congregación de Israel hubiere errado, y el yerro estuviere oculto a los ojos del pueblo, y hubieren hecho algo contra alguno de los mandamientos de Jehová en cosas que no se han de hacer, y fueren culpables; 4:14 luego que llegue a ser conocido el pecado que cometieren, la congregación ofrecerá un becerro por expiación, y lo traerán delante del tabernáculo de reunión.

50 Números, 5: 11 a 31.

51 Deuteronomio, 17: 6 Por dicho de dos o de tres testigos morirá el que hubiere de morir; no morirá por el dicho de un solo testigo. 
Si se analiza la estructura punitiva del Antiguo Testamento, resulta claro que se hace una diferenciación entre las penas que se aplican a los judíos (que van desde ofrecer un sacrificio hasta la muerte) y aquellas que se aplican a los no judíos (casi de forma indefectible el exterminio). Las normas contenidas en el Pentateuco regulan la interrelación entre personas del pueblo judío casi en su totalidad; cuando se hace referencia a la interacción con personas de otros pueblos, en la mayoría de los casos es bajo instrucción, ya sea de respetar su vida, ya de exterminar.

Esta estructura dicotómica, judío y no judío. parte del presupuesto de la existencia de un pueblo elegido, esto es, aquel con quien Dios ha establecido una alianza específica y, por supuesto, implica la existencia de otros pueblos que no gozan de la gracia de la divinidad y cuya relación puede ser de respeto mutuo, como sucede con los edomitas, descendientes de Esaú, o los egipcios de tercera generación, o bien de intolerancia total y exterminio, como sucede con los amonitas y moabitas, descendientes de Lot, así como con la casi totalidad de pueblos cananeos que los rodeaban (LALINDE ABADÍA, op. cit., p. 532). Esta diferenciación se origina en la historia bíblica de la Torre de Babel, en la cual se relata la forma en que Jehová castigó la vanidosa pretensión del ser humano de prevenirse contra futuros diluvios y cataclismos, mediante la construcción de una torre en la que pudiera refugiarse, tan alta que llegara hasta el cielo. Conforme el relato bíblico ${ }^{52}$, "tenían todos los hombres una misma lengua y las mismas palabras", produciéndose la "confusión de lenguas" como castigo divino. Vale señalar que el texto bíblico no especifica cuál es el idioma único y universal que se hablaba antes, aún cuando los intérpretes originales señalaban que era el hebreo, opinión compartida por los Padres de la Iglesia, desde Orígenes a San Agustín (Colodenco, 2006, p. 88). Los sumerios afirmaban también, en los relatos de Enmerkar y el señor de Aratta, sobre la existencia de un período primigenio en el que existía un solo idioma universal, luego de lo cual el dios Enki "cambió el lenguaje que había en sus bocas... que hasta entonces había sido uno" (ídem, p. 89). Si tenemos en cuenta que el lenguaje es el componente fundamental de una cultura, resulta claro que se plantea la diferencia cultural como castigo de Dios ${ }^{53}$.

Esta parte del Génesis sirve como fundamento para la construcción posterior del concepto de pueblo elegido por Dios, que, como hemos visto, marca transversalmente las relaciones sociojurídicas de los miembros del pueblo judío y de este con los demás pueblos que lo circunscriben.

Esta construcción dicotómica a la que hacemos referencia, o mejor dicho la negación de la validez de la misma, es justamente uno de los puntos respecto de los cuales

52 Génesis, 11.

53 Sobre este tema debe citarse a Derrida, quien señala que "el lenguaje ha empezado sin nosotros, en nosotros antes que nosotros. Es lo que la teología denomina Dios, y hay que, habrá habido que hablar" (DERRIDA, 1997). 
las enseñanzas cristianas hacen mayor hincapié ${ }^{54}$. En los evangelios se nos muestra a un Jesús claramente crítico con la diferenciación jurídica teológica entre judíos y no judíos, bajo fórmulas como "todos somos iguales ante Dios". Paradójicamente, el mayor gestor del universalismo cristiano, Saulo o Pablo de Tarso, es el que sienta las bases para la construcción de una nueva estructura dicotómica de castigo, con la inclusión del concepto de "hereje" en su epístola a Tito ${ }^{55}$. La palabra hereje viene del griego hairetikos (el que divide por pensar) (Beekes, 2010, 2 Vol. 1) ${ }^{56}$. Ya no será la pertenencia racial a un pueblo determinado, sino la adscripción o no al credo cristiano, lo que determinará el lado en que una persona se encontrará dentro de la estructura punitiva, que girará posteriormente alrededor de los conceptos de prójimo y hereje, y que será un milenio después el fundamento de aquello que conocemos actualmente como la Inquisición o el Santo Oficio.

\section{BIBLIOGRAFÍA}

Beekes, Robert Stephen Paul (2010). Etymological Dictionary of Greek. Brill: Leiden.

CARDASCia, Guillaume (1979). La place du talion dans l'histoire du droit pénal á la lumière des droits du Proche-Orient ancient, Tolouse: Centre d'historie juridique méridionale.

Chambliss, Rollin (1954). Social Thought from Hammurabi to Comte. New York: The Dryden Press.

Cohen, BoAz (1965). Evidence in Jewish Law. Rec. Bodin, XVI.

Cruveilhier, Pierre (1938). Commentaire du Code d'Hammourabi. Paris: Librairie Ernest Leroux.

CuQ, EdouARD (1929). Études sur le Droit babylonien, Les lois assyriennes et les lois hittites. Paris: Libraire Orientaliste Paul Geuthner.

Gaudemet, Jean (2006). Les naissances du droit, Montchrestien. Paris.

54 Génesis, 11:1

55 Tito, $3: 10$

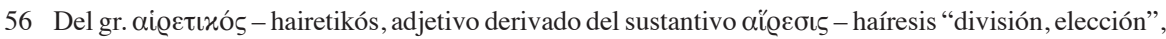

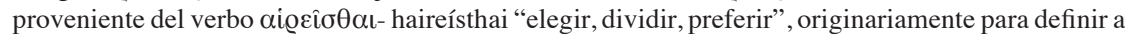
personas pertenecientes a otras escuelas de pensamiento, es decir, que tienen ciertas "preferencias" en ese ámbito. 
GIRARD, RENÉ (2005). La violencia y lo sagrado (cuarta edición). Barcelona: Anagrama.

GIRARD, RENÉ (2002). El chivo expiatorio, 2. a ed. Barcelona: Anagrama.

Goldstein, Mateo (1947). Derecho hebreo, a través de la Biblia y el Talmud. Buenos Aires: Editorial Atalaya.

Koschaker, Paul (1991). Babylonisch-Assyrisches Bürgschaftsrecht. Leipzig: Scientia Verlag.

KoschaKer, PAul (1917). Rechtsvergleichende Studien zur Gesetzgebung Hammurabis Königs von Babylon. Leipzig: Veit \& Comp.

LALINDE ABADÍA, JESÚs (1992). Las culturas represivas de la humanidad. Zaragoza: Universidad de Zaragoza.

LARA PEINAdo, Federico y LARA GONZÁLEZ, FEDERICO (2009). Estudio introductorio en Los primeros códigos de la humanidad. Madrid: Tecnos.

MAnzini, Vincenzo (1903). "Il diritto criminale nella piú antica legge consciuta en Revista Penale, vol. LVII, fasc. VI. Torino: Unione Tipografico Editrice, Torino.

PAVly, JEAN DE (1896). Code civil et pénal du judaïsme. Paris: Ernest Leroux Editor.

Pérez Prendes, José Manuel (1970). Apuntes para la bibliografía histórica del Derecho hebreo. Primer Simposio de Estudios Sefardíes, Actas CSIC, Madrid.

RABINOVICH-BERKMAN, RICARDO (2006). Recorriendo la historia del Derecho. Quito: Editorial Cevallos.

Thureau-Dangin, Francois (1905). Les inscriptions de Sumer et d'Akkad. Paris: Leroux. 